\title{
PENGARUH EKSTRAK ETHANOL PROPOLIS TERHADAP EKSPRESI PROTEIN Bcl2, CYCLIN D1 DAN INDUKSI APOPTOSIS PADA KULTUR SEL KANKER KOLON
}

\author{
THE EFFECT OF ETHANOL EXTRACT OF PROPOLIS TOWARD BCL2 PROTEIN \\ \& CYCLIN D1 EXPRESSION AND INDUCED APOPTOSIS CANCER CELLS IN \\ CULTURE KOLON
}

\author{
Haryono Yuniarto, Sumardi Maryono, Bambang Purwanto \\ Sub Bagian Hematologi Onkologi Medik, Bagian Ilmu Penyakit Dalam \\ FK UNS / RSUD Dr. Moewardi Surakarta \\ Korespondensi: Haryono Yuniarto: drharyonoyuniarto@gmail.com
}

\begin{abstract}
ABSTRAK
Kanker kolorektal menempati urutan kejadian kanker ketiga di seluruh dunia, dengan lebih dari 1 juta angka kejadian tiap tahunnya. Berbagai strategi terapi pengobatan kanker kolorektal tetapi relatif belum optimal. Oleh karena itu, terdapat kebutuhan mengembangkan terapi alternatif sebagai pendamping. Propolis menunjukkan aktivitas proapoptosis pada berbagai jenis sel kanker. Mengetahui pengaruh pemberian propolis yang berasal dari Kerjo, Karanganyar, Indonesia terhadap induksi proses apoptosis dan aktivitas antiproliferasi, terutama terkait dengan penekanan ekspresi protein Bcl 2 dan cyclin D1 pada kultur sel WiDr (cell line kanker kolon). Penelitian eksperimental laboratorik menggunakan post test with control group design. Penelitian dilakukan pada kultur sel WiDr (sel kanker kolon) dengan pemberian propolis. Pengamatan ekspresi protein Cyclin DI dan Bcl2 dilakukan dengan metode imunositokimia, sedangkan pengamatan induksi apoptosis dilakukan dengan flowcytometry. Analisis statistik dengan uji Kruskal-Wallis, signifikan bila $p<0,05$. Rata-rata ekspresi Bcl2 pada kelima kelompok yaitu kontrol $83.40 \pm 0.69 \mu \mathrm{g} / \mathrm{ml}$, EEP $1 / 2 \mathrm{IC}_{50} 60.63 \pm 0.40$, EEP IC $5033.77 \pm 1.08 \mu \mathrm{g} / \mathrm{ml}$, EEP $2 \mathrm{IC}_{50} 24.28 \pm 1.91 \mu \mathrm{g} / \mathrm{ml}$, 5fluorouracil $12.74 \pm 2.19 \mu \mathrm{g} / \mathrm{ml}$. Terdapat perbedaan bermakna ekspresi Bcl2 antara kelompok uji dibandingkan kelompok kontrol $(p<0,001)$. Rata-rata ekspresi cyclin D1 pada kelima kelompok yaitu kontrol $83.77 \pm 0.39 \mu \mathrm{g} / \mathrm{ml}$, EEP $1 / 2 \mathrm{IC}_{50} 61.44 \pm 0.41$, EEP IC $30.67 \pm 1.18 \mu \mathrm{g} / \mathrm{ml}$, EEP $2 \mathrm{IC}_{50} 24.50 \pm$ $0.38 \mu \mathrm{g} / \mathrm{ml}$, 5fluorouracil $13.42 \pm 1.04 \mu \mathrm{g} / \mathrm{ml}$. Terdapat perbedaan bermakna ekspresi cyclin D1 antara kelompok uji dibandingkan kelompok kontrol $(p<0,001)$. Pemberian ekstrak etanol propolis mempunyai pengaruh menekan ekspresi Bcl2, cyclin D1, dan menginduksi apoptosis pada kultur sel kanker kolon (WiDr Cell Line).
\end{abstract}

Kata Kunci: Ekstrak Ethanol Propolis, Bcl2, cyclin D1, Sel WiDr

\section{ABSTRACT}

Colorectal cancer ranks third in cancer incidence worldwide, with more than 1 million number of events each year. There are various therapeutic strategies for colorectal cancer treatment but relatively not optimal. Therefore, there is a need to develop alternative therapies as a companion. Propolis shows proapoptosis activity on various types of cancer cells. The aim of this study to determine the effect of propolis originating from Kerjo, Karanganyar, Indonesia to perform induction of apoptosis and anti-proliferation activities, mainly associated with suppression of protein expression of Bcl 2 and cyclin D1 in cell culture WiDr (colon cancer cell line). The study used laboratory experimental post-test with control group design. The study was conducted on cell cultures WiDr (colon cancer cells) by administering propolis. Observation of Cyclin D1 protein expression and Bcl-2 was conducted using immunocytochemistry, whereas induction of apoptosis observations made by flowcytometry. Statistical analysis used the Kruskal-Wallis test, significant if $p<0.05$. The average expression of Bcl-2 in five groups: control $83.40 \pm 0.69 \mathrm{pg} / \mathrm{ml}$, EEP $1 / 260.63 \pm 0.40$ IC50, IC50 EEP $33.77 \pm 1.08 \mathrm{pg} / \mathrm{ml}$, EEP 2 IC50 24.28 $\pm 1.91 \mathrm{pg} / \mathrm{ml}, 12.745$ fluorouracil $\pm 2: 19 \mathrm{ug} / \mathrm{ml}$. Bcl2 expression significantly different between the test group and the control group $(p<0.001)$. The average expression of cyclin D1 in five groups: control $83.77 \pm 0: 39 \mathrm{ug} / \mathrm{ml}$, EEP 1/2 61.44 $\pm 0: 41$ IC50, IC50 EEP 1:18 $\pm 36.67 \mathrm{pg} / \mathrm{ml}$, EEP 2 IC50 24.50 $\pm 0: 38 \mathrm{ug} / \mathrm{ml}$, 5fluorouracil 13:42 $\pm 1: 04 \mathrm{ug} / \mathrm{ml}$. There is a significant difference between the expression of cyclin D1 test group than the control 
group $(p<0.001)$. The ethanol extract of propolis has a suppresive effect on the expression of Bcl-2, cyclin D1, and induces apoptosis in cultured colon cancer cells (WiDr Cell Line).

Keywords: Ethanol Propolis Extract, Bcl-2, cyclin D1, WiDr Cells

\section{PENDAHULUAN}

Kanker sampai saat ini tercatat sebagai salah satu masalah kesehatan utama, baik di negara maju maupun negara berkembang. Kanker merupakan penyakit dengan karakteristik adanya gangguan atau kegagalan mekanisme pengaturan multiplikasi pada organisme multiseluler sehingga terjadi perubahan perilaku sel yang tidak terkontrol. Menurut National Cancer Institute (2009) kanker adalah suatu istilah untuk penyakit yang melibatkan pembelahan sel secara abnormal, tanpa kontrol dan dapat menyerang jaringan sekitarnya.Sel-sel yang mengalami transformasi terus-menerus berproliferasi dan menekan pertumbuhan sel normal.

Angka kematian disebabkan oleh kanker termasuk tinggi. Di seluruh duniasekitar 14,1 juta kasus baru dan 8,2 juta kematian akibat kanker (Torre dkk., 2015). Data dari WHO (World Health Organization), 2003, menyatakan bahwa kematian akibat kanker dapat mencapai angka 45\% dari tahun 2007 hingga 2030, yaitu sekitar 7,9 juta jiwa menjadi 11,5 juta jiwa kematian. Di Indonesia, kanker merupakansalah satu masalah utama kesehatan di masyarakat dengan angka kejadian4,3 per 1000 penduduk dan menjadi penyebab kematian kelima setelah stroke, tuberculosis, diabetes melitus dan trauma kepala (Depkes RI., 2009).

Kanker kolorektal atau dikenal dengan kanker usus besar adalah penyakit keganasan yang terjadi pada kolon, rektum, dan appendix (usus buntu). Kanker kolorektal menempati urutan kejadian kanker ketiga di seluruh dunia, dengan lebih dari 1 juta angka kejadian tiap tahunnya. Kanker kolorektal adalah salah satu kanker dengan angka kematian tertinggi di dunia (Globocan dkk., 2013 dan Siegel dkk., 2014). Di Indonesia, kanker kolorektal adalah jenis keganasan di bagian gastroenterohepatologi yang menempati urutan kedua sesudah kanker hepatoseluler (Kurniawati dan Tenggara, 2011).

Mortalitas yang tinggi pada pasien kanker kolorektal dipengaruhi oleh kemampuan kanker tersebut untuk metastasis ke organ yang jauh (Ottaiano dkk., 2006). Sekitar 20\% dari kasus kanker kolorektal yang telah metastasis ini pada umumnya inoperable dan relatif tidak dapat disembuhkan dengan 5-year survival rate sebesar 12\% (Wang dan Zhang, 2014). Terdapat enam perubahan mendasar dalam fisiologi sel yang menentukan fenotif ganas suatu kanker diantaranya. Menghasilkan sendiri sinyal pertumbuhan, insensitivitas terhadap sinyal penghambat pertumbuhan, menghindari apoptosis, kemampuan replikasi tanpa batas, kemampuan angiogenesis yang berkelanjutan, kemampuan invasi dan metastasis ke jaringan lain (Robin dan Cotran., 2007). Meskipun berbagai upaya telah dicapai pada penanganan kanker, namun masih ditemui rendahnya laju ketahanan hidup pasien. Hal ini mendasari pengembangan penelitian agen-agen lain sebagai terapi pendamping terapi standart.

Propolis adalah suatu zat yang dihasilkan oleh lebah madu, mengandung resin dan lilin lebah, bersifat lengket yang dikumpulkan dari sumber tanaman, terutama dari bunga dan pucuk daun, untuk kemudian dicampur dengan air liur lebah (Marcucci dkk., 2001; Salatino dkk., 2005; dan Nakajima dkk., 2009). Propolis telah dibuktikan mempunyai berbagai aktivitas biologis seperti antibakteri, antijamur, antivirus, anestetik lokal, antiinflamasi, antioksidan, hepatoprotektor, imunostimulator, serta berperan pada proses penyembuhan luka (Paulino dkk., 2009; Vatansever dkk., 2010; Kubina dkk., 2015). Komposisi senyawa kimiawi dan aktivitas biologi propolis bervariasi tergantung lokasi geografi, asal tanaman, musim dan spesies lebah (Paulino dkk., 2009 dan Syamsudin dkk., 2009).

Salah satu hal yang menjanjikan dari propolis, yaitu terkait dengan aktivitas antikanker yang dimilikinya. Peran propolis di dalam terapi keganasan terkait dengan kemampuannya dalam aktivitas antiproliferasi dan menginduksi apoptosis. Pada berbagai penelitian in vitro propolis menunjukkan aktivitas anti kanker pada berbagai jenis sel kanker, meliputi : kanker laring, kanker paru, kanker pankreas, kanker thyroid, kanker kolorektal, kanker payudara, kanker prostat dan glioma (Kubina dkk., 2015). 
Mekanisme apoptosis terjadi melalui dua jalur utama, jalur ekstrinsik dan intrinsik. Apoptosis jalur intrinsik diregulasi oleh sekelompok protein. Protein $\mathrm{Bcl} 2$ adalah protein yang bersifat anti apoptosis, bekerja dalam mitokondria, berperan pada fase inisiasi apoptosis jalur intrinsik. Penurunan aktivitas $\mathrm{Bcl} 2$ akan menyebabkan peningkatan apoptosis dan sebaliknya. Apoptosis merupakan mekanisme untuk mengontrol proliferasi sel (Ghobrial dkk., 2005).

Proliferasi sel bergantung pada kelangsungan siklus sel. Cyclin D1, berperan sentral pada siklus sel. Cyclin D1 akan berikatan dengan cyclin D kinase, kompleks cyclin D-CDK ini akan memfosforilasi protein retinoblastoma (pRB) yang mengkode protein-protein untuk kelangsungan dari siklus sel. Cyclin D1 aktif bila berikatan dengan CDk. Hal ini menunjukkan bahwa cyclin D1 merupakan starter dari siklus sel (Alison, 2001).

Berdasarkan fakta-fakta yang diuraikan di atas, mendorong peneliti untuk mengetahui pengaruh pemberian propolis yang berasal dari Kerjo, Karanganyar, Indonesia terhadap aktivitas anti kanker, terkait dengan ekspresi protein Cyclin D1 dan Bcl2 serta induksi apoptosis pada kultur sel WiDr (cell line kanker kolorektal).

\section{METODE PENELITIAN}

Penelitian ini merupakan penelitian eksperimental laboratorik dengan menggunakan post test with control group design. Penelitian dilakukan pada kultur sel WiDr (sel kanker kolon) dengan pemberian propolis. Pengamatan ekspresi protein Cyclin D1 dan Bcl2 dilakukan dengan metode imunositokimia, sedangkan pengamatan induksi apoptosis dilakukan dengan flowcytometry. Analisis statistik menggunakan uji Kruskal-Wallis, signifikan bila $\mathrm{p}<0,05$.

\section{HASIL DAN PEMBAHASAN}

1. Uji sitotoksisitas dengan MTTassay untuk menetapkan nilai $\mathrm{IC}_{50}$ EEP dan 5 Fluorouracil.

Uji sitotoksik ekstrak ethanol propolis (EEP) pada sel WiDr (cell line kanker kolon) untuk menentukan dosis IC ${ }_{50}$ yang digunakan. Data yang didapat dari uji sitotoksisitas dengan MTT assay berupa absorbansi dari tiap sumuran yang merupakan hasil pembacaan dengan ELISA reader dengan panjang gelombang $595 \mathrm{~nm}$.

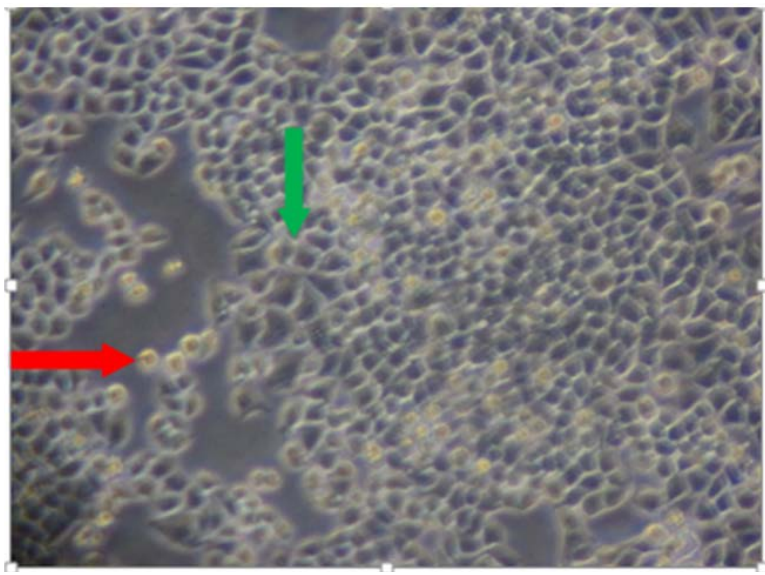

Gambar 1. Morfologi Sel WiDr, sel hidup ditunjukkan panah hijau dan sel mati ditunjukkan panah merah. Sel diamati dengan mikroskop inverted dengan perbesaran $100 \mathrm{x}$

Data tersebut kemudian diolah lebih lanjut dengan cara membandingkan nilai absorbansi antara sel yang diberi perlakuan EEP, $5 \mathrm{Fu}$ dan kontrol (sel tanpa perlakuan) setelah masingmasing dikurangi dengan kontrol media untuk mendapatkan persentase viabilitas sel. Persentase viabilitas sel ini kemudian digunakan untuk mendapatkan persentase hambatan proliferasi sel, yang selanjutnya akan digunakan untuk menentukan $\mathrm{IC}_{50}$ bahan uji.

Tabel 1. Nilai rata-rata persentase hambatan proliferasi sel WiDr dan nilai $\mathrm{IC}_{50}$ senyawa bahan uji dengan metode MTT assay

\begin{tabular}{cccc}
\hline Bahan Uji & $\begin{array}{c}\text { Konsentrasi } \\
(\mathrm{ug} / \mathrm{ml})\end{array}$ & $\begin{array}{c}\text { Rata-rata viabilitas } \\
\text { sel WiDr }(\% \pm \mathrm{SD})\end{array}$ & $\begin{array}{c}\mathrm{IC}_{50} \pm \mathrm{SD} \\
(\mathrm{ug} / \mathrm{ml})\end{array}$ \\
\hline & 12,5 & $126,60 \pm 7,92$ & \\
Ekstrak & 25 & $103,93 \pm 7,23$ & \\
Etanol & 50 & $67,78 \pm 1,63$ & $139,61 \pm 49,48$ \\
Propolis & 100 & $34,48 \pm 2,10$ & \\
(EEP) & 200 & $15,31 \pm 1,75$ & \\
& & & \\
\hline
\end{tabular}




\begin{tabular}{llll}
\hline Bahan Uji & $\begin{array}{c}\text { Konsentrasi } \\
(\mathbf{u g} / \mathbf{m l})\end{array}$ & $\begin{array}{c}\text { Rata-rata viabilitas } \\
\text { sel WiDr }(\% \pm \mathbf{S D})\end{array}$ & $\begin{array}{c}\mathbf{I C}_{\mathbf{5 0}} \pm \mathbf{S D} \\
(\mathbf{u g} / \mathbf{m l})\end{array}$ \\
\hline \multirow{5}{*}{$5-\mathrm{FU}$} & 12,5 & $118,57 \pm 5,57$ & \\
& 25 & $114,17 \pm 3,83$ & \\
& 50 & $112,61 \pm 6,86$ & $502,33 \pm 60,52$ \\
& 100 & $105,37 \pm 3,09$ & \\
& 200 & $91,27 \pm 4,86$ & \\
\hline
\end{tabular}

Berdasarkan tabel 1 bahan uji baik EEP maupun $5 \mathrm{Fu}$ mampu menghambat proliferasi sel WiDr. Hal ini ditunjukkan dengan semakin meningkatnya konsentrasi bahan uji semakin sedikit persentase viabilitas sel WiDr. Dari analisis regresi linear diperoleh $\mathrm{IC}_{50}$ EEP adalah 139,61 $\mathrm{ug} / \mathrm{ml}$. Nilai $\mathrm{IC}_{50}$ EEP ini selanjutnya digunakan untuk dasar penentuan konsentrasi EEP yang digunakan pada uji penelitian selanjutnya, yaitu sebesar 70, 140, dan $280 \mathrm{ug} / \mathrm{ml}\left(1 / 2 \mathrm{IC}_{50} \mathrm{IC}_{50}\right.$, dan $\left.2 \mathrm{IC}_{50}\right)$. Nilai $\mathrm{IC}_{50} 5 \mathrm{FU}$ akan digunakan sebagai pembanding pada uji imunositokimia dan induksi apoptosis dengan flowcitometry, yaitu sebesar $502,33 \mathrm{ug} / \mathrm{ml}$.

\section{Pengamatan ekspresi protein cyclin D1}

Pengamatan dengan pengecatan imunositokimia untuk cyclin D1 dilakukan pada 5 kelompok perlakuan (Kontrol negatif, 1/2 $\mathrm{IC}_{50}$, $\mathrm{IC}_{50} 2 \mathrm{IC}_{50}$ dan $\mathrm{IC}_{50} 5 \mathrm{Fu}$ ), dan masing-masing kelompok perlakuan tersebut dibuat triplicate. Data yang didapatkan berupa persentase sel yang mengekspresikan protein cyclin D1 (terlihat sebagai warna coklat pada inti sel maupun sitoplasma) dari keseluruhan sel pada 5 lapangan pandang dan penilaiannya dilakukan 3 kali dari tiap-tiap kelompok perlakuan. Hasil pengecatan imunositokimia untuk ekspresi protein cyclin D1 pada sel WiDr masing-masing kelompok ditampilkan pada Gambar 2. Data keseluruhan untuk persentase ekspresi protein cyclin D1 pada sel WiDr dengan pemberian EEP, $5 \mathrm{Fu}$ maupun kelompok kontrol, ditampilkan pada Grafik yang dapat dilihat pada gambar 3 :

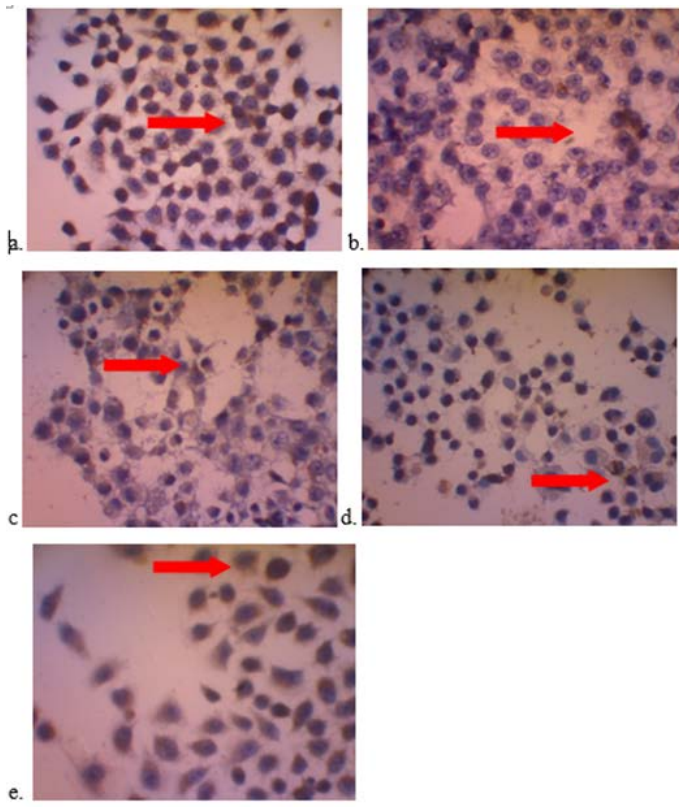

Gambar 2. Hasil pengecatan imunositokimia perbesaran 400 kali untuk ekspresi cyclin D1 pada sel WiDr setelah perlakuan dan inkubasi selama 24 jam pada kelompok kontrol (a), kelompok dengan EEP konsentrasi $\frac{1}{2} \mathrm{IC}_{50}$ (b), $\mathrm{IC}_{50}(\mathrm{c}), 2 \mathrm{IC}_{50}(\mathrm{~d})$ dan $\mathrm{IC}_{50} 5 \mathrm{FU}$. Sel yang mengekspresikan cyclin D1 ditunjukkan dengan panah warna merah.

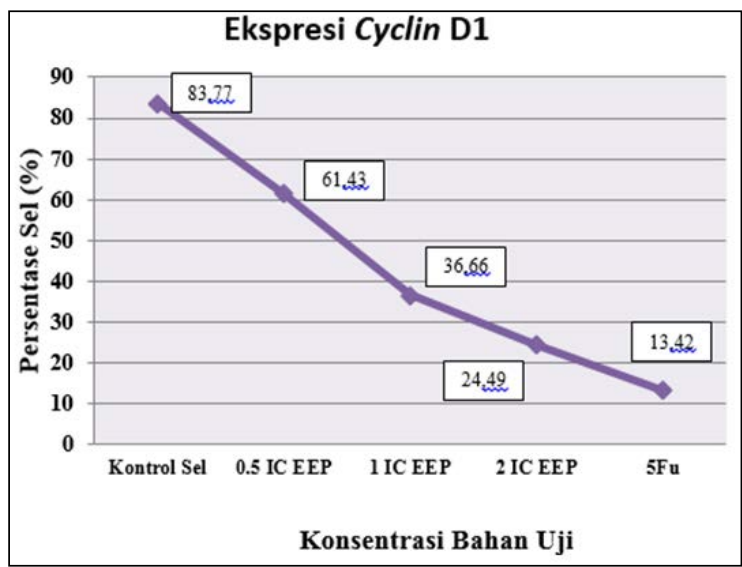

Gambar 3. Grafik hubungan konsentrasi EEP dengan ratarata persentase ekspresi cyclin $\mathrm{D} 1$ pada sel WiDr setelah inkubasi 24 jam 
Dari grafik di atas, tampak bahwa dengan pemberian EEP selama 24 jam dapat menekan ekspresi protein cyclin D1. Penekanan ekspresi protein cyclin D1 ini sebanding dengan peningkatan konsentrasi EEP yang diberikan. Dari hasil uji statistik tersebut menunjukkan bahwa terdapat perbedaan ekspresi protein cyclin D1 yang bermakna diantara kelompok perlakuan yang mendapatkan EEP konsentrasi $70 \mathrm{ug} / \mathrm{ml}, 140 \mathrm{ug} /$ $\mathrm{ml}$ dan $280 \mathrm{ug} / \mathrm{ml}$ dibandingkan dengan kelompok kontrol.

\section{Pengamatan ekspresi protein $\mathbf{B c l} 2$}

Pengamatan ini dilakukan dengan menggunakan pengecatan imunositokimia terhadap protein $\mathrm{Bcl} 2$ pada 5 kelompok perlakuan (Kontrol, 1/2 $\mathrm{IC}_{50} \mathrm{IC}_{50} 2 \mathrm{IC}_{50}$ dan $5 \mathrm{Fu}$ dosis $\mathrm{IC}_{50}$ ). Masing-masing kelompok perlakuan tersebut dibuat triplicate. Data yang didapatkan berupa persentase sel yang mengekspresikan protein $B c l 2$ (terlihat sebagai warna coklat pada inti sel maupun sitoplasma) dari keseluruhan sel pada 5 lapangan pandang dan penilaiannya dilakukan pada 3 slide dari tiap-tiap kelompok perlakuan. Hasil pengecatan imunositokimia untuk protein Bcl2 pada sel WiDr tampak pada Gambar.

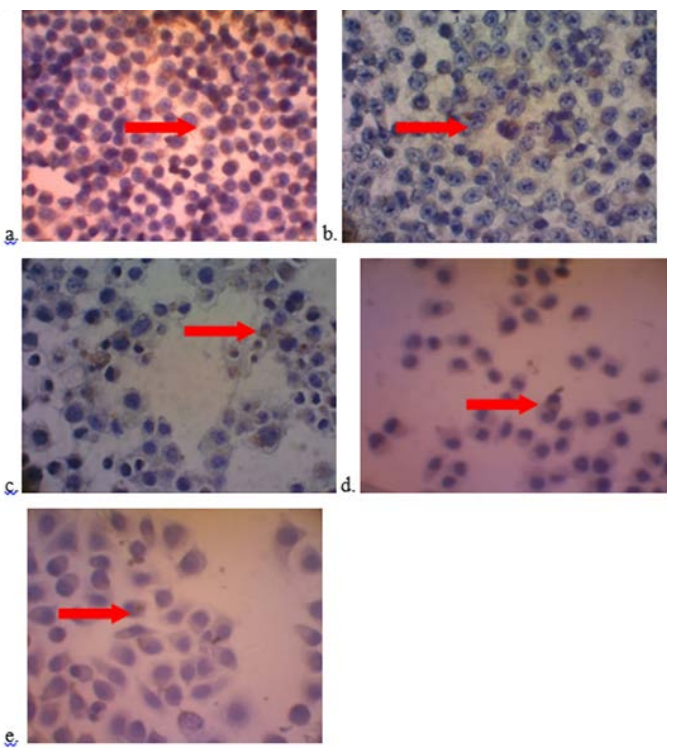

Gambar 4. Hasil pengecatan imunositokimia perbesaran 400 kali untuk ekspresi protein $B c l 2$ pada sel WiDr setelah perlakuan dan inkubasi selama 24 jam pada kelompok kontrol (a), kelompok dengan pemberian EEP dengan konsentrasi $1 / 2 \mathrm{IC}_{50}(\mathrm{~b}), \mathrm{IC}_{50}(\mathrm{c}), 2 \mathrm{IC}_{50}(\mathrm{~d})$ dan $5 \mathrm{Fu}$ dosis $\mathrm{IC}_{50}$. Sel yang mengekspresikan protein $\mathrm{Bcl} 2$ ditunjukkan dengan panah warna merah
Data persentase ekspresi protein $\mathrm{Bcl} 2$ pada sel WiDr dengan pemberian EEP maupun kelompok kontrol, ditampilkan pada Grafik hubungan antara konsentrasi EEP dengan rata-rata persentase ekspresi protein $\mathrm{Bcl} 2$ pada sel $\mathrm{WiDr}$ dapat dilihat pada Gambar

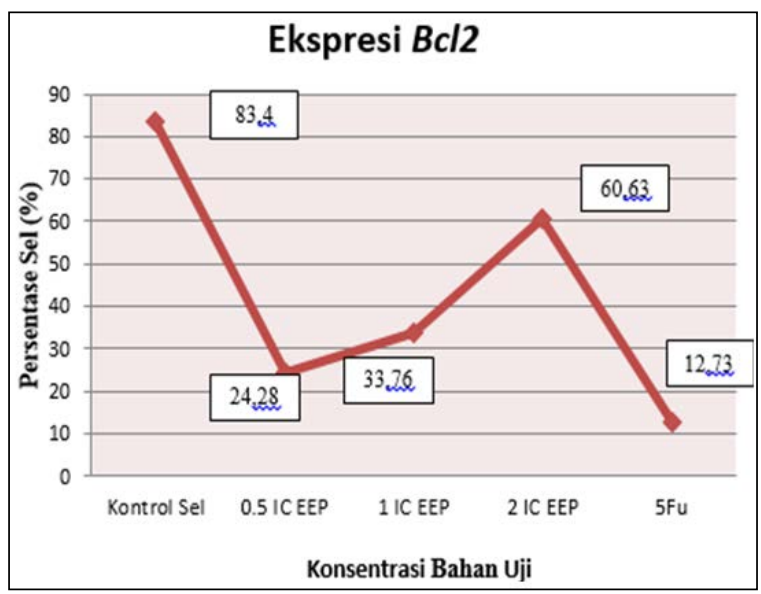

Gambar 5. Grafik hubungan konsentrasi EEP dengan ratarata persentase ekspresi $B c l 2$ pada sel WiDr setelah inkubasi 24 jam

Dari Grafik di atas, terlihat bahwa dengan pemberian EEP selama 24 jam dapat menurunkan persentase protein $B c l 2$ positif pada sel WiDr. Penurunan persentase protein $\mathrm{Bcl} 2$ positif pada sel WiDr ini didapatkan paling banyak pada pemberian EEP dosis 1/2 IC50. Dari Grafik di atas, terlihat bahwa dengan pemberian EEP selama 24 jam dapat menurunkan persentase protein $\mathrm{Bcl} 2$ positif pada sel WiDr. Penurunan persentase protein $\mathrm{Bcl} 2$ positif pada sel WiDr ini didapatkan paling banyak pada pemberian EEP dosis $1 / 2$ IC50.

Hasil uji statistik menunjukkan ada perbedaan ekspresi protein $\mathrm{Bcl} 2$ yang bermakna diantara kelompok perlakuan yang mendapatkan EEP konsentrasi 70, 140 maupun $280 \mathrm{ug} / \mathrm{ml}$ dibanding dengan kelompok kontrol.

\section{Uji induksi apoptosis EEP pada sel WiDr dengan flowcytometry}

Uji induksi apoptosis dengan flowcitometry dilakukan pada lima kelompok perlakuan, yaitu kelompok dengan pemberian EEP (dosis $1 / 2 \mathrm{IC}_{50}$, $\mathrm{IC}_{50}$ dan $\left.2 \mathrm{IC}_{50}\right)$, kelompok dengan pemberian $5 \mathrm{Fu}$ (dosis $\mathrm{IC}_{50}$ ), dan kelompok kontrol tanpa perlakuan. Morfologi sel WiDr pada kelima kelompok tersebut setelah dilakukan inkubasi selama 48 jam tampak pada Gambar 6 

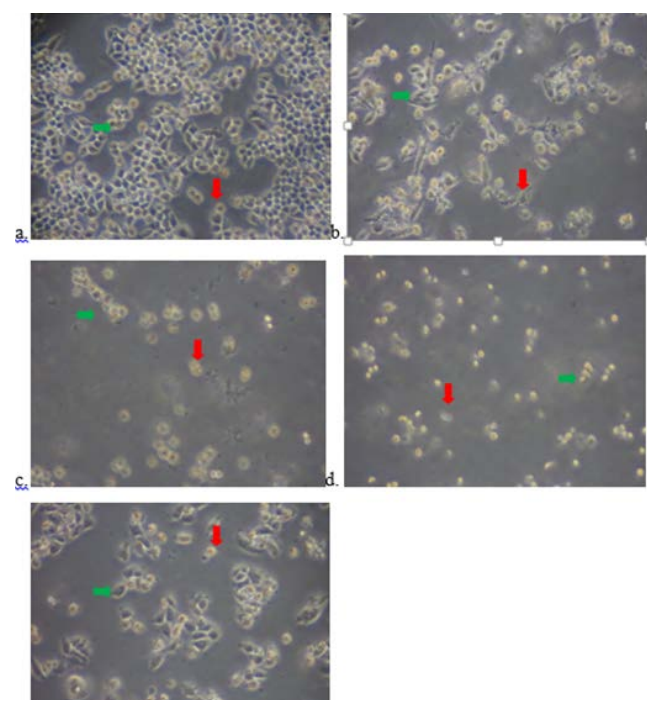

Gambar 6. Gambar sel WiDr dengan perbesaran 100 kali, untuk uji apoptosis setelah inkubasi 48 jam pada kelompok kontrol (a), kelompok dengan pemberian EEP konsentrasi $70 \mathrm{ug} / \mathrm{ml}$ (b), $140 \mathrm{ug} / \mathrm{ml}$ (c), $280 \mathrm{ug} / \mathrm{ml}$ (d), serta kelompok dengan pemberian $5 \mathrm{Fu} 500 \mathrm{ug} / \mathrm{ml}$ (e). Sel hidup ditunjukkan dengan panah warna hijau, sedangkan sel mati dengan panah warna merah.

Hasil flowcytometry secara lengkap disertakan pada gambar 7, sedangkan rata-rata persentase sel $W i D r$ yang mengalami apoptosis pada kelima kelompok ditampilkan pada tabel 2

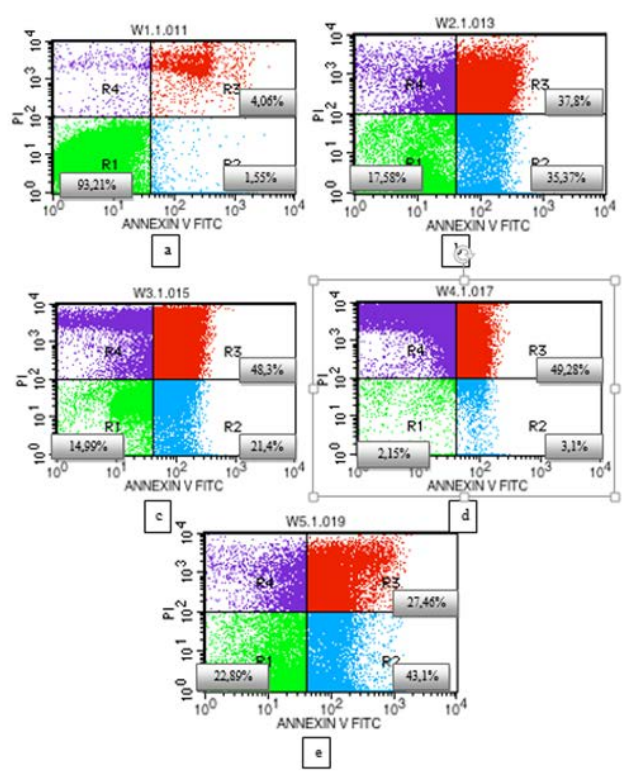

Gambar 7. Hasil flowcytometry sel WiDr setelah perlakuan dan inkubasi selama 24 jam pada kelompok kontrol (a), kelompok dengan pemberian EEP konsentrasi $1 \frac{1}{2} \mathrm{IC}_{50}(\mathrm{~b})$, $\mathrm{IC}_{50}(\mathrm{c})$ dan $2 \mathrm{IC}_{50}(\mathrm{~d})$ serta kelompok dengan pemberian 5-FU konsentrasi $\mathrm{IC}_{50}(\mathrm{e})$
Tabel 2. Rata-rata persentase sel WiDr yang mengalami apoptosis setelah inkubasi selama 24 jam dengan bahan uji

(EEP dan 5-FU) maupun pada kelompok kontrol.

Perlakuan Konsentrasi (ug/mL) Rata-rata Apoptosis SelWiDr $(\%) \pm \mathrm{SD}$

\begin{tabular}{lll}
\hline Kontrol Sel & 0 & $1,55 \pm 0,05$ \\
EEP & $70\left(1 / 2 \mathrm{IC}_{50}\right)$ & $35,37 \pm 1,2$ \\
& $140\left(\mathrm{IC}_{50}\right)$ & $21,88 \pm 0,67$ \\
& $280\left(2 \mathrm{IC}_{50}\right)$ & $3,11 \pm 0,13$ \\
$5 \mathrm{FU}$ & $500\left(\mathrm{IC}_{50}\right)$ & $43,16 \pm 0,45$ \\
\hline
\end{tabular}

Data yang ditunjukan pada tabel 2 menunjukkan bahwa Konsentrasi EEP pada dosis $1 / 2 \mathrm{IC}_{50}$ mampu menginduksi apoptosis paling tinggi pada sel $\mathrm{WiDr}$ dibandingkan dengan konsentrasi EEP yang lain (dosis $\mathrm{IC}_{50}$ dan $2 \mathrm{IC}_{50}$ ). Hal ini menunjukkan bahwa semakin besar konsentrasi EEP yang diberikan akan menginduksi terjadinya nekrosis pada sel $W i D r$.

Hasil uji statistik menunjukkan adanya perbedaan yang bermakna diantara kelima kelompok perlakuan. Hasil multiple comparisons menunjukkan bahwa ada perbedaan rata-rata persentase apoptosis sel yang bermakna secara statistik pada semua kelompok. Perbedaan yang tidak bermakna secara statistik terdapat diantara kelompok perlakuan yang mendapat EEP konsentrasi $280 \mathrm{ug} / \mathrm{mL}\left(2 \mathrm{IC}_{50}\right)$ dibanding dengan kelompok kontrol positif (5FU).

Pada penelitian ini diawali dengan uji sitotoksisitas EEP pada sel WiDr menggunakan metode MTT assay. Uji sitotoksisitas ini dilakukan untuk menetapkan nilai $\mathrm{IC}_{50}$ EEP yang selanjutnya akan digunakan sebagai dasar penetapan konsentrasi EEP untuk pengamatan penekanan ekspresi cyclin D1, Bcl2 maupun uji induksi apoptosis pada sel WiDr. Selain itu, uji sitotoksisitas ini juga digunakan untuk menetapkan $\mathrm{IC}_{50} 5$ fluorouracil pada sel WiDr sebagai senyawa pembanding pada uji induksi apoptosis.

Pada uji sitotoksisitas ini secara umum didapatkan persentase hambatan proliferasi sel WiDr semakin meningkat sebanding dengan peningkatan konsentrasi EEP yang diberikan (Tabel.2). Hal ini menunjukkan bahwa pemberian EEP konsentrasi $70-280 \mathrm{ug} / \mathrm{mL}$ pada penelitian ini selama 24 jam mampu menghambat proliferasi sel WiDr. Hal ini sesuai dengan penelitian Ishihara dkk., (2009) mengenai efek anti proliferasi dari ekstrak etanol propolis yang berasal dari Cina dan Brazil pada cell line kanker kolorektal dimana 
ekstrak etanol propolis menghambat pertumbuhan dari cell line kanker kolorektal.

Pada hasil analisis diperoleh $\mathrm{IC}_{50} \mathrm{EEP}$ pada sel WiDr dipenelitian ini sebesar 139,32 ug/mL. Szliszka dkk., (2011) melaporkan bahwa konsentrasi EEP $50 \mathrm{ug} / \mathrm{mL}$ dari Negara Polandia bagian selatan mempunyai efek sitotoksisitas $25 \%$ pada cell linekanker prostat. Vatansever dkk., (2010) menunjukkan bahwa EEP konsentrasi 125 $\mathrm{ug} / \mathrm{mL}$ mempunyai efek sitotoksik pada sel MCF7 (cell line kanker payudara). Vatansever dkk., (2010) juga melaporkan bahwa terdapat perbedaan efek sitotoksik dari tujuh sampel EEP yang berbeda yang dikumpulkan dari lokasi yang sama. Penelitian ini mengindikasikan bahwa komposisi kimia dan farmakokinetik EEP berbeda-beda. Hal ini selain dipengaruhi oleh geografis juga dipengaruhi jenis tanaman, asal propolis tersebut diperoleh.

Grafik hubungan antara konsentrasi EEP dengan rata-rata persentase ekspresi cyclin D1 pada sel WiDr (Gambar 12) menunjukan bahwa pemberian EEP selama 24 jam menekan ekspresi cyclin D1 yang sebanding dengan peningkatan konsentrasi EEP yang diberikan. Hasil uji statistik menunjukkan perbedaan ekspresi cyclin D1 yang bermakna secara statistik terdapat diantara kelompok perlakuan yang mendapatkan EEP dibandingkan dengan kelompok kontrol. Penekanan cyclin D1 mengakibatkan penurunan pembentukan kompleks cyclin D1-CDK sehingga siklus sel berhenti pada fase G0/G1 dan terjadi penghambatan proliferasi sel WiDr.

Grafik hubungan antara konsentrasi EEP dengan rata-rata persentase protein $\mathrm{Bcl} 2$ pada sel WiDr (Gambar 13) terlihat bahwa dengan pemberian EEP selama 24 jam dapat menurunkan persentase protein $\mathrm{Bcl} 2$ positif pada sel WiDr. Penurunan persentase protein $\mathrm{Bcl} 2$ positif pada sel WiDr ini didapatkan paling banyak pada pemberian EEP dosis $1 / 2$ IC50. Hasil uji statistik menunjukkan adaya perbedaan ekspresi $\mathrm{Bcl} 2$ yang bermakna secara statistik diantara semua kelompok perlakuan dibandingkan dengan kelompok kontrol. Penekanan ekspresi protein Bcl2 dimana yang berfungsi sebagai protein antiapoptosis selanjutnya akan menginduksi terjadinya apoptosis.

Hasil ini sesuai dengan penelitian Motomura dkk., (2008) yang melaporkan bahwa ekstrak methanol propolis mampu meningkatkan apoptosis cell line U-937 (sel kanker leukemia) melalui aktivasi caspase-3 dan penekanan $\mathrm{Bcl}$ 2. Penelitian lain oleh Diana dkk., (2012) dan Kubina dkk., (2015), menunjukan propolis diketahui dapat menginduksi aktivitas protein lain yang terlibat dalam proses pro-apoptosis,seperti $B a x$, dan menekan ekspresi $B c l-2$ yang merupakan inhibitor apoptosis.

Penelitian ini terdapat keterbatasan diantaranya, pengamatan penekanan ekspresi cyclin D1 dan Bcl2 dilakukan dengan metode imunositokimia. Meskipun teknik ini relatif sederhana dan prosedurnya mudah dilakukan, namun hasilnya ditentukan oleh banyak faktor seperti pengalaman teknisi dan subyektivitas pengamat yang menginterpretasi hasil.

\section{SIMPULAN}

1. Pemberian ekstrak ethanol propolis mampu menekan ekspresi protein cyclin D1 pada kultur sel WiDr.

2. Pemberian ekstrak ethanol propolis mampu menekan ekspresi protein $\mathrm{Bcl} 2$ pada kultur sel WiDr.

3. Pemberian ektsrak propolis mampu menginduksi apoptosis pada kultur sel WiDr.

\section{DAFTAR PUSTAKA}

Alison, M.R. 2001. Cancer. In :Encyclopedia of Life Seciences. Nature Publishing Group. London. United Kingdom.

Departemen Kesehatan RI (Depkes RI). 2009. Profil Kesehatan Indonesia 2008. Departemen Kesehatan Republik Indonesia. Jakarta.

Diana S, Halina C, Maria H, Jacek N.2012. The anticancer activity of propolis. Folia hisyochemica et cytobiologica. Vol 50, No 1,pp 25-37

Ghobrial IM, Witzig TE, Adjei AA.2005, Targeting apoptosis pathways in cancer therapy. CA Cancer J Clin. 55(3):178-94. 
Globocan. 2013. Cancer Fact Sheets for Colorectal Cancer.2013. Available from: URL: http://globocan. iarc.fr/Pages/fact_sheets_cancer.aspx

Ishiara M, Naoi K, Hashita M, Itoh Y, Suzui M. 2009. Growth inhibitory activity of ethanol extracts of Chinese and Brazilian propolis in four human colon carcinoma cell lines. Oncol Rep. 22: 349-354.

Kurniawati, A dan Tenggara, R. 2011. Pengaruh Asam Asetil Salisilat terhadap Penurunan Prevalensi Kanker Kolorektal. CDK. 186: 38(5): 350-352.

Kubina, R., Dzik, A.K., Dziedzic, A., Bielec, B., Wojtczka, R.D., Buldok, R.J., Wysznynska, M., et al. 2015. The ethanol extract of polish propolis exhibits anti-proliferative and/or pro-apoptotic effect on HCT 116 colon cancer and Me45 malignant melanoma cell in vitro conditions. AdvClinExp Med. 24(2): 203-212.

Marcucci MC, Ferreres F, Garc a-Viguera C, Bankova VS, De Castro SL, Dantas APet al, 2001. Phenolic compounds from Brazilian propolis with pharmacological activities. J Ethnopharmacol;74:p.105-12.

Motomura, M., Kwon, K.M., Suh, S.J. 2008. Propolis induces cell cycle arrest and apoptosis in human leukemic U937 cells through Bcl-2/Bax regulation. Environ ToxicolPharmacol. 26:61-67.

Nakajima, Y., Tsuruma, K., Shimazawa, M., Mishima.S., Hara, H. 2009. Comparison of Bee Products Based on Assays of Antioxidant Capacities. Nagaragawa Research Center. Department of Biofunctional Evaluation, Molecular Pharmacology, Gifu Pharmaceutical University, 5-61 Mitahora-higashi, Gifu 502-8585. Japan. Published online by Journal BioMed Central Medicine, 1472- 6882/9:4

National Cancer Institute, 2009. What is cancer?. National Institute of Health. United States.

Ottaiano, A., Franco, R., Aiello, T.A., Liguori, G., Tatangelo, F., Delrio, P., Nasti, G., et al. 2006. Overexpression of bothCXC chemokine receptor 4 and vascular endothelial growth factorproteins predicts early distant relapse in stage II-III colorectalcancer patients. Clin Cancer Res. 12: 2795-2803.

Paulino, N., Abreu, S.R.L., Machodo, G., Silveira, E. 2009. Scientific evidences to pharmacological anticancer action of Baccharisdracunculifolia Brazilian propolis. Rev PesqInov Farm. 1(1): $15-26$.

Robbins and Cotran, Pathologic Basis of Disease. 7th ed. WB Saunders Co. Philadelphia, 2005:309-13

Salatino A, Teixeira EW, Negri G, and Message D, 2005. Origin and Chemical Variation of Brazilian Propolis. Evid Based Complement Alternat Med 2(1): p.33-8

Siegel, R., Ma, J., Zou, Z., Jemal, A. 2014. Cancer statistics.CACancer J Clin.64: 9-29.

Syamsudin, Wiryowidagdo, S., Simanjuntak, P., Heffen, W.L. 2009. Chemical composition of propolis from different region in java and their cytotoxic activity. AJBB. 5(4): 180-183.

Torre, L.A., Bay, F., Siegel, R.L., Ferlay, J., Tieulent, J.L., Jemal, A. 2015. Global Cancer Statistic. $C a$ Cancer J Clin. 65: 87-108.

Vatansever, H.S., Sorkun, K. Gurhan, S.I.D., Ozdal-Kurt, F., Turkoz, E., Gencay, O., Salih, B. 2010. Propolis from Turkey induces apoptosis through activating caspases in human breast carsinoma cell lines. ActaHistochem. 112: 546-556.

Wang, X dan Zhang, Y. 2014. Targeting mTOR network in colorectal cancer therapy. World $J$ Gastroenterol. 20(15): 4178-4188.

World Health Organization, International Agency for Research on Cancer, 2003. Human cancers by organ site; colorectal cancer. In: Stewart BW, Kleihues P, eds. World cancer report. Lyon, France: IARC Press, p:198-202. 